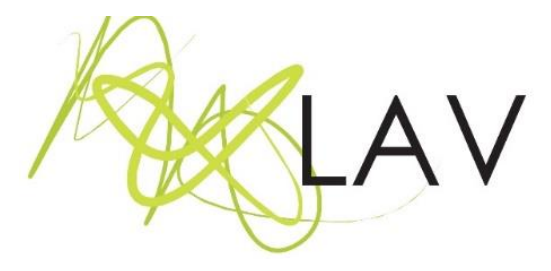

\title{
Educação estética e (auto)formação: singularidades no tornar-se docente
}

\author{
Aesthetic education and (self)training: singularities in teaching
}

Ana Cristina Moraes ${ }^{i}$

Universidade Estadual do Ceará

\section{Resumo}

O artigo reflete sobre formação estética com esteio na trajetória de uma docente do ensino superior. Numa perspectiva autobiográfica, discorre sobre experiências estéticas desde a infância até a atuação profissional numa universidade pública, no âmbito do ensino, pesquisa e extensão. O texto ampara-se em autores de referência, como Suassuna (1996, 2008), Freire (2006), Josso (2007), Tardif (2007), Souza (2008), Duarte Junior (2010) e Martins $(2011,2014)$. Categorias como autobiografia, educação estética e formação docente são criticamente discutidas. Infere-se que uma formação docente de bases estéticas requer um rico e contínuo acesso a vivências estético-culturais, em especial artísticas, que envolvam possibilidades de apreciação, criação e análises de obras de artes. Conclui-se que cada docente, pela sua singular história de vida e acessos a formações e acervos culturais, cria um repertório e um modo peculiar de tornar-se docente, o que compõe um conjunto diversificado de docentes em atuação no campo da educação estética.
\end{abstract}

Palavras-chave: autobiografia, educação estética, formação, docência.

\section{Abstract}

The article reflects on aesthetic training with a mainstay in the trajectory of a higher education teacher. From an autobiographical perspective, she discusses aesthetic experiences from childhood to professional performance in a public university, in the scope of teaching, research and extension. The text is supported by reference authors such as Suassuna (1996, 2008), Freire (2006), Josso (2007), Tardif (2007), Souza (2008), Duarte Junior (2010) e Martins $(2011,2014)$. Categories such as autobiography, aesthetic education and teacher training are critically discussed. It is inferred that a teacher training with aesthetic bases requires a rich and continuous access to aesthetic-cultural experiences, especially artistic ones, involving possibilities of appreciation, creation and analysis of works of art. It is concluded that each teacher, due to their unique life history and access to cultural formations and collections, has a repertoire and a peculiar way of becoming a teacher, which creates a diverse group of teachers working in the field of aesthetic education.

Keywords: autobiography, aesthetic education, training, teaching. 


\section{Introdução}

Estes escritos fazem parte dos desdobramentos reflexivos de uma pesquisa ${ }^{1}$ envolvendo formação docente de pedagogos, e que ensejou reflexões sobre a formação da própria autora-pesquisadora, o que contribuiu significativamente para guiar e fundamentar a pesquisa referida e compreender mais detidamente um processo de constituição da docência.

Por situar-me como docente que pensa e exercita ações estético-pedagógicas, discorro sobre instantes de minha trajetória de educação estética, especialmente por meio de experiências artísticas desde a infância até a atuação acadêmico-profissional no âmbito do ensino superior. E também sobre a reverberação de elementos dessa trajetória em ações docentes. Escrevo esse texto em primeira pessoa do singular, deixando mais nítido o caminho que percorri e que me fez criar identificações com o assunto. Nesta escritura, também realizo uma (auto)formação - referendando a perspectiva apontada por Josso (2007) - ao esforçar-me por lembrar, refletir e aprender com fatos por mim vivenciados ao longo do tempo, num "[...] trabalho transformador de si, ligado à narração das histórias de vida e a partir delas" (JOSSO, 2007, p. 413).

Tendo claro que minhas aprendizagens, em boa medida, se deram por conta dos acessos a variados saberes culturais que tive ao longo da vida, registro algumas lembranças, permeada pela percepção de que as aprendizagens de meus alunos também exigem o nutrir-me cotidianamente desses saberes, na condição de docente (TARDIF, 2007). Para Tardif (2007, p. 263) os saberes docentes são "temporais, plurais e heterogêneos", além de serem personalizados, por se constituírem também a partir da subjetividade e da história de vida dos professores. Junto disso, como docente, assumo também o papel de mediadora cultural (MARTINS, 2014), mobilizando saberes socioculturais em meio às práticas pedagógicas.

Com um olhar muito particular, infantil até - já que muitas lembranças cravadas na memória foram produzidas na infância, e com um modo próprio de percepção do mundo tento estabelecer imagens de fatos ocorridos nessas esquinas e vielas, que fizeram parte de meu processo estético-educativo; sendo que esse processo traz a forte marca das buscas e nutrições antropofágicas (BARCELOS; SILVA, 2008), imerso no desejo de aprender, de ampliar os horizontes, de crescer. Essa nutrição, no entanto, é também

\footnotetext{
1 Pesquisa de Doutorado intitulada "Educação Estética em práticas antropofágicas na ampliação do repertório artístico-cultural de estudantes (UECE)", curso realizado de 2012 a 2015 na UNICAMP-SP.
} 
guiada por oportunidades, escolhas e situações inusitadas que foram se delineando em minha trajetória.

A ideia de auto(formação) expressa é aqui narrada na perspectiva de uma abordagem experiencial, onde, com arrimo em uma (auto)biografia educativa, "[...] o sujeito produz um conhecimento sobre si, sobre os outros e o cotidiano, o qual revela-se através da subjetividade, da singularidade, das experiências e dos saberes, ao narrar com profundidade" (SOUZA, 2008, p. 90). Com isso, no decorrer do texto, teço algumas reflexões sobre minha atuação acadêmica, profissional e pessoal, as quais foram surgindo concomitantemente a minha prática cotidiana, como condição elementar da própria atuação, ou seja, um processo reflexivo que se deu na prática e sobre a prática (SCHÖN, 2000).

Muitas vezes "a gente estuda aquilo que nos falta". Esta fala, de uma professora, em meio às discussões numa das aulas da disciplina "Imagens, corpo e educação" (2012.1) na Universidade Estadual de Campinas - UNICAMP - me fez refletir por um bom tempo sobre o porquê de eu escolher estudar educação estética e, olhando retrospectivamente minha trajetória de vida, vi que essa frase tem muito significado e se relaciona com minha experiência. Faltaram-me, em certa medida, estímulos que me garantissem experimentações estéticas mais densas em minha formação, especialmente por meio das Artes. Hoje busco aperfeiçoar essa dimensão estética, investindo nesse campo de saber, seja com estudos teóricos, seja com apreciações de obras artísticas diversas, seja ainda com experimentações em teatro e literatura ou no trabalho pedagógico em arte-educação na universidade. E foi com esteio nisso que o presente artigo se desenvolveu num contínuo construto de significados para minha vida e para a formação de professores em que estou envolvida, tendo a prerrogativa da educação estética como alicerce. O poema a seguir trata isso. Ele foi por mim produzido com substrato nas reflexões surgidas na disciplina a pouco citada.

\section{AUSÊNCIAS}

Um valor ao que lhe falta

O carente atribui

Um sentido na busca

Menos pelo que intui.

Quer a mais, o complemento

Incompletude, sempre, uma lacuna 
Olhar pedinte, fraco servo do acaso

A contemplar o nada sobre a móvel duna.

O pouco que the pertence

De muito apego já desgasta

Clemente custo de cuidar a isso

Por tanto esforço, viver não basta.

(Ana Cristina Moraes)

\section{Da infância na escola e na família às vivências no meio universitário}

É guiada pela ideia de (auto)formação, inspirada em Josso (2007), que desenvolvo os escritos a seguir, em meio a um esforço contínuo de reflexão e transformação de si.

Abordar o conhecimento de si mesmo pelo viés das transformações do ser - sujeito vivente e conhecente no tempo de uma vida, através das atividades, dos contextos de vida, dos encontros, acontecimentos de sua vida pessoal e social e das situações que ele considera formadoras e muitas vezes fundadoras, é conceber a construção da identidade, ponta do iceberg da existencialidade, como um conjunto complexo de componentes. De um lado, como uma trajetória que é feita da colocação em tensão entre heranças sucessivas e novas construções e, de outro lado, feita igualmente do posicionamento em relação dialética da aquisição de conhecimentos, de saber-fazer, de saber-pensar, de saber-ser em relação com o outro, de estratégias, de valores e de comportamentos, com os novos conhecimentos, novas competências, novo saber-fazer, novos comportamentos, novos valores que são visados através do percurso educativo escolhido (JOSSO, 2007, p. 420).

Ao tentar recobrar da memória vivências envolvendo experiências estético-artísticas na infância, vejo o quanto é difícil, e até um pouco frustrante, a falta de imagens que remetam a isso de modo significativo. É como se fosse a prova concreta da precariedade de meu acesso a uma educação estética (principalmente formal) por meio de experiências artísticas. No primeiro momento, entretanto, remeto-me aos discos de vinil que ganhara de meus pais e ouvia diariamente, e "viajava" nas histórias infantis - a mais marcante e que até hoje eu a conto integralmente é "Era uma vez uma batatinha" (da Coleção Disquinho) - e também acompanhava com meu cantar as músicas de clássicos como os vinis do "Palhaço Carequinha" e de "Os Trapalhões". Lembro-me ainda do quanto eu desejava fazer ballet clássico, por influências midiáticas ou por ver outras coleguinhas fazendo, porém, nunca tendo realizado este desejo pelo fato de ser pago (e caro, para os padrões financeiros de minha família na época) e também por não ser uma necessidade

Revista Digital do LAV - Santa Maria - vol. 11, n. 2, p.20 - 39 - mai./ago. 2018 ISSN 1983 - 7348

http://dx.doi.org/10.5902/1983734830973 
de primeira ordem, na concepção familiar. Assim, carreguei essa ausência por muito tempo, junto com o fato de que eu era muito tímida e, por exemplo, nas festinhas de criança que eu frequentava, nem tinha coragem de dançar e chegava até mesmo a achar bobo aquilo tudo. Como eu iria e queria dançar ballet com esse pensamento? Hoje vejo nisso um contrassenso. Talvez o desejo de fazer ballet fosse um impulso consumista que me invadia naquela época.

Em um click da memória, veio-me ainda a imagem marcante de um poema da Cecília Meireles ("A bailarina") que eu lia bastante na infância e creio que ele também colaborou para instigar meu desejo de menina: "[...] Esta menina tão pequenina/quer ser bailarina/mas depois esquece todas as danças/e também quer dormir como as outras crianças". - um poema que alimentou muito meu imaginário infantil.

Em meu tempo de criança (mais precisamente nos anos 1980), era muito comum ter representantes de editoras nas ruas, vendendo coleções de livros, enciclopédias, dicionários etc., de porta em porta. Meus pais compraram, para mim e meus três irmãos, algumas dessas coleções - capa dura - tanto para pesquisas escolares como para leituras cotidianas. Encantei-me com uma coleção de literatura infantil, de autores diversos e com ilustrações coloridas! Passava boa parte do dia a folhear e a ler os textos escritos e as imagens. Além desse "tesouro" de capa dura, lembro-me de que aprendi a gostar muito de ler com os livrinhos de bolso que meu pai sempre trazia de viagem e que eram de histórias de faroeste (ou bang bang), ao estilo de séries e filmes como "Os imperdoáveis" (1992), de Clint Eastwood, dentre tantos outros. Esses livros narravam histórias por demais violentas, envolvendo vinganças, trapaças e romances. Eram, no entanto, para mim muito envolventes, além de que eram alguns dos livros que eu tinha acesso dentro de casa. É claro que eu também lia muitos gibis - como os da "Turma da Mônica", "Tio Patinhas" etc. - e que também adorava, mas ler os livrinhos de faroeste era como ler hoje os contos brutais de Rubem Fonseca. Foram, pois, essas referências literárias iniciais, trazidas por meu pai, que me fizeram aprender a gostar de ler.

$\mathrm{Na}$ escola, precisamente no Ensino Fundamental (ingressei na escola com seis anos, na chamada, à época, "alfabetização"), até ensaiei participar de festas juninas e desfiles cíveis e de "rainha do milho", mas, em razão da minha retração e timidez, talvez fruto de uma educação moral e religiosa muito intensa, esse empreendimento não me era muito prazeroso; ao contrário, sentia-me insegura e incomodada com o fato de estar tão exposta, apesar de, contraditoriamente, achar muito bonito aquilo tudo e querer estar lá no lugar

Revista Digital do LAV - Santa Maria - vol. 11, n. 2, p.20 - 39 - mai./ago. 2018 ISSN 1983 - 7348 http://dx.doi.org/10.5902/1983734830973 
de quem se apresentava. Só algum tempo depois, já pré-adolescente, participava desses eventos com maior prazer e motivação.

Sobre experiências estéticas na escola, vivenciei algumas aulas de Artes ( $5^{\circ}$ ano), nas quais era priorizado o trabalho manual - pintura em cerâmica, por exemplo - e a escrita de textos literários. Gostava muito de fazer trabalhos manuais, pois percebia minha criatividade sendo estimulada, em movimento. E ver um trabalho finalizado e poder leválo para casa era muito gratificante, pois, intimamente, eu queria que meus pais vissem um resultado belo daquilo que eu gostava de fazer.

Em relação à escrita literária, lembro-me de que o professor de Artes (que era o mesmo de Redação) pediu certa vez que elaborássemos uma história, com enredo e ilustrações em forma de livro, todo original. Dividi esse trabalho com meu irmão - que na época estudava na mesma sala. Foi mais uma experiência frustrante, pois o professor estabeleceu prazo de entrega e exigia um bom trabalho. Sentindo-me pressionada, não conseguia elaborar nada, nem meu irmão. Então tivemos a ideia de reproduzir, à mão, uma história infantil que tínhamos em casa (daquela coleção de capa dura referida), com algumas alterações. O professor, ao corrigir, percebeu o terrível plágio e nos deu uma nota bem baixa (acho que um 6,5). Fiquei envergonhada com esse desempenho, mas tentei esquecer, apesar de passar um bom tempo sem conseguir encará-lo novamente. Contraditoriamente, sempre gostei de ler e de escrever e não entendo por que não consegui desenvolver esse trabalho a não ser pela via da falta de orientação e de estímulo do professor que, no dia da entrega das notas dos trabalhos, exerceu ainda a prática de exaltar os que tiraram nota máxima, para aumentar ainda mais minha angústia.

No contexto escolar, à época em que eu fazia o Ensino Fundamental e Médio, nos anos 1980 e princípio dos de 1990, não era conferida ênfase ao ensino de artes; ao contrário, era pouco significativo esse campo de conhecimento. Tanto é que tenho rasas lembranças ou aprendizagens significativas. Havia, porém, os momentos de eventos festivos e datas comemorativas, como as festas juninas, dia das mães e dos pais, páscoa, independência do Brasil, quando desfilávamos nas ruas - disso eu recordo gostar muito, apesar de serem eventos clichês, até hoje exercidos em instituições educativas. Em uma das escolas onde estudei, havia diariamente o hasteamento da bandeira e o canto do hino nacional, atividade um tanto maçante, mas às vezes eu gostava desse ritual, em respeito e valorização ao País. Tinha um espírito cívico intensivo na adolescência.

Fora da escola, tive algumas experiências que considero de caráter estético, principalmente em meus períodos de férias que passava em Pernambuco, tanto no interior do Estado como 
no Recife, minha terra natal. Períodos de Carnaval, São João e festas natalinas no Recife e em Olinda são muito intensos e sempre gostei desses momentos tão coloridos e dançantes. Dançava muito em meio às multidões, já que ficava quase anônima no meio da massa, podia me liberar das amarras morais e dos problemas de timidez. $\mathrm{Na}$ adolescência, essas referências pernambucanas me influenciaram muito na produção de artesanato e na atração por máscaras de tipos diversos. Comecei a fazer também, influenciada pela minha avó e tias, peças em tecidos coloridos (que, no Recife-PE chamam de 'putucas' e em Fortaleza-CE chamam de 'fuxicos'), além de roupinhas para bonecas e bijuterias. Bem mais tarde, aprendi a bordar e produzi muitas peças que considerei belas. O enxoval do Bernardo, meu primeiro filho, foi bordado por mim, o que muito me orgulha. Também produzi (mais recentemente) alguns estandartes, sob influência dos grupos de maracatus de Pernambuco, com cetim e bordado com lantejoulas para doar ao Grupo de Teatro de Rua "Flor do Sol" (Icapuí-CE), para o movimento docente e estudantil "Em defesa da UECE", para a Banda de Lata da Faculdade de Educação de Itapipoca - FACEDI, e que foram expostos nas apresentações e mobilizações coletivas. Vejo, nesse trajeto, muitas referências culturais do Nordeste do Brasil inspirando minhas produções, manifestando o que disse a respeito dos ensinamentos de Suassuna (2008) sobre a identificação e a valorização de nossos elementos culturais.

Encontrava-me nessas produções, pois não precisava me expor. Minha exposição se dava pela peça elaborada. O silêncio e o recato eram necessários para essa elaboração. Talvez por isso eu gostasse tanto de fazer trabalhos manuais, pois me preservava. Essa lembrança do gosto pelo trabalho manual, e pelo fazer arte de modo mais introspectivo, fez-me refletir sobre minhas escolhas em relação ao teatro, linguagem artística com a qual mais me identifico e exerço até hoje. Primeiramente, envolvi-me com teatro de bonecos, pois acreditava que essa modalidade teatral continuaria a me preservar, a me esconder, já que eu ficava atrás da cortina e era o boneco quem iria atuar! Quando era estudante do Curso de Serviço Social na Universidade Estadual do Ceará - UECE - com início em 1994 - tive a oportunidade de fazer e depois ministrar oficinas de teatro de bonecos e me encantei com essa possibilidade de criar bonecos (o trabalho manual mais uma vez), criar enredos para a história a ser encenada e pôr o boneco em cena. Depois que fui me apropriando desse saber, passei a trabalhar com o teatro de bonecos em meio às atividades do movimento estudantil, fazendo passagens em sala com diversos colegas que compuseram, junto comigo, duas gestões do centro acadêmico. Após essas aprendizagens, fui realizando oficinas formativas entre os estudantes e em atuações profissionais como estagiária de Serviço Social. Na Universidade, também vivenciei a aprendizagem de produzir máscaras 
de gesso, o que me direcionou a ministrar uma oficina de caráter mais profissional numa importante livraria de Fortaleza, em meados dos anos 1990, bem como em oficinas de formação de professores e de terapeutas comunitários em organizações não governamentais - ONGs.

As formações teatrais - de palco, de rua e Teatro do Oprimido (BOAL, 2005) - foram se dando, principalmente, por vontade de transgredir meus limites, pois eu sentia intensa necessidade de romper com certas inibições e acreditava, firmemente, que o teatro me possibilitaria isso, o que em parte foi verdade. Essas aprendizagens realizadas em cursos livres coincidiram com meu período de atuação na UECE que se estende até hoje.

Marcante nesse processo, e que destaco, foi a experiência formativa em Teatro do Oprimido oferecida pelo Centro do Teatro do Oprimido, sediado no Rio de Janeiro, e que realizou suas ações de modo descentralizado, indo para diversas cidades do País, para realizar um trabalho de multiplicação dessa modalidade teatral. No Ceará, formou-se uma turma de multiplicadores em que eu e outra professora da UECE nos inserimos para participar. Após um curso de 80 horas, dividido em duas etapas, produzimos peças de Teatro do Oprimido para exibição pública e também realizamos, então como ministrantes, oficinas e cursos formativos na UECE e em outros espaços socioeducativos, como, por exemplo, o Centro Cultural do Banco do Nordeste do Brasil (em 2008). Produzimos duas peças dessa modalidade teatral que resultaram em diversas sessões de teatro-fórum em variados lugares, como na I Mostra de Arte Contemporânea em Itapipoca-CE e no I Festival de Teatro do Oprimido em Fortaleza-CE (ambos em 2008).

No decorrer de 2012, participei de um curso livre de teatro em Campinas - SP, no Barracão Teatro que, ao final da formação (em dezembro/2012), resultou numa peça teatral exibida por três noites seguidas em espetáculo público, tendo o espaço lotado todas as noites. 0 Curso Livre foi um grande achado, tanto em relação aos vínculos pessoais que fiz, pois não conhecia quase ninguém na cidade no período de realização do Doutorado (2012 a 2015), quanto no que concerne à experiência de formação teatral, pois vim também para Campinas com a intenção de buscar essa formação. Com outras nove pessoas que fizeram o Curso Livre do Barracão, dei continuidade aos trabalhos teatrais, com a criação da Companhia de Araki, em que permaneci durante o ano de 2013, participando de ensaios, oficinas de formação e escrevendo projeto em edital para circulação do nosso espetáculo. Ainda em 2013, fiz um dos cursos de fevereiro no LUME, a Oficina-montagem abre-alas que finalizou com um belo cortejo nas ruas de Barão Geraldo (bairro em que morava e que é sede do LUME), numa sexta-feira, abrindo o carnaval daquele ano. Esta foi uma atividade

Revista Digital do LAV - Santa Maria - vol. 11, n. 2, p.20 - 39 - mai./ago. 2018 ISSN 1983 - 7348 http://dx.doi.org/10.5902/1983734830973 
muito intensa, tanto física² como artisticamente, onde adquiri outros saberes teatrais, no sentido da composição de um cortejo, da elaboração de figurino e maquiagem, da ampliação de meu repertório de exercícios e jogos teatrais, da percepção de que o condicionamento e a ação física são essenciais a uma produção teatral etc. Em setembro de 2015 facilitei uma oficina denominada "cortejo brincante" no evento nacional IX Ciência em Cena ocorrido em Itapipoca-CE e que foi baseada nos saberes vivenciados nesta formação que tive no LUME. O resultado da oficina foi maravilhoso, apresentamos uma peça ao final do evento e o encerramos com uma grande ciranda. O resultado desta intervenção repercutiu bastante pelo encantamento da cena elaborada, bem como, pelo envolvimento e alegria dos participantes.

O fato de eu coordenar o Núcleo de Artes Cênicas - NACE - da FACEDI/UECE, me fez sentir a necessidade de aprofundamentos, pois minha formação em teatro se baseava em oficinas diversas e em curso livre que frequentei no Teatro José de Alencar - TJA - em 2010 (Fortaleza), mas não pude concluir a elaboração do espetáculo final. No curso do Barracão Teatro citado, encontrei pessoas mais maduras (no TJA havia muitos adolescentes, não me identifiquei muito com o grupo) e também tive a oportunidade de ter uma direção, já que nossas peças no NACE são dirigidas coletivamente. Considerei muito importante essa experiência e percebi que avancei bastante em meio a tantas aprendizagens significativas. Faço, pois, cursos livres e oficinas de teatro desde 2005 e até tentei cursar uma graduação em Artes Cênicas no Instituto Federal de Educação-CE - IFCE em 2007.2, onde consegui fazer um semestre, mas depois tive que abandonar em razão das aulas serem todos os dias, na Capital, e meu trabalho ser em Itapipoca-CE, não dando para conciliar as duas coisas naquele momento.

No decorrer de minha formação universitária nos cursos de mestrado e doutorado em Educação (UFC ${ }^{3}$ e UNICAMP, respectivamente), também experienciei alguns momentos de formação estético-artística em meio às aulas e ao desenvolvimento de pesquisas de campo. Para esta (no mestrado - 2001-2002), trabalhei com a abordagem sociopoética ${ }^{4}$, um referencial teórico-metodológico que, dentre outros princípios, valoriza a criação artística dos sujeitos de pesquisa como elemento essencial à produção de dados, além de acreditar numa perspectiva coletiva na realização desse processo, tomando o grupo pesquisador (formado pelo pesquisador-proponente e sujeitos do campo de pesquisa) como dispositivo.

\footnotetext{
${ }^{2}$ Após oito dias de curso, fiquei com os joelhos inflamados, com dificuldades para me locomover, porém, mais condicionada e centrada para as cenas.

${ }^{3}$ Universidade Federal do Ceará.

${ }^{4}$ A esse respeito, ver: GAUTHIER, Jacques. Sociopoética: encontro entre arte, ciência e democracia na pesquisa em ciências humanas e sociais, enfermagem e educação. Salvador-BA: UFBA, 1999.
} 
Assim, com essa abordagem, percebi o quanto uma elaboração artística é, ao mesmo tempo, um saber e também um instrumento tradutor de variados saberes, se tomada como ponte para a explicação ou análise de um dado assunto.

No âmbito do ensino, cito uma experiência marcante da disciplina Movimentos Sociais, Educação Popular e Escola, mediante a qual me lembro vivamente da produção coletiva da colcha de retalhos. Esta se configurou como uma forma de avaliação final da disciplina, quando cada estudante recebia um pedaço de tecido quadrado e nele teria que elaborar, criativamente, uma imagem que expressasse algo sobre os saberes desenvolvidos na disciplina. Numa aula seguinte, todos teriam que expor a produção e falar no que tinham refletido para compor a peça. Na sequência, uma das estudantes que havia trazido uma máquina de costura portátil ia costurando as peças, formando uma grande colcha que ficou bem bonita. Considerei este momento muito interessante, metafórico, poético, já que fortalecia em mim a beleza de uma elaboração coletiva na criação e apreensão de saberes. Tal experiência, para mim marcante, foi também para muitos de meus alunos, pois levei esta ideia como exercício para diversas disciplinas que ministrei.

Ao final do mestrado em 2002, por conta da defesa da dissertação, convidei o Grupo de Teatro de Rua Flor do Sol (Icapuí-CE) para expressar, por meio de espetáculo teatral, algumas discussões tidas pelo Grupo Pesquisador no decorrer do estudo ${ }^{5}$. Diversos integrantes do Grupo Flor do Sol também participaram do Grupo Pesquisador.

Em 2012, com o ingresso na UNICAMP para o curso de Doutorado - no Laboratório de Estudos sobre Arte, Corpo e Educação (LABORARTE) - vivenciei algumas experimentações estético-artísticas em sala de aula, também significativas, pois, a cada encontro, os professores coordenadores do Grupo iniciavam ou finalizavam as discussões e apresentações de trabalhos com vivências diversas de que todos participavam - ciranda, música, dança pessoal, alongamentos, expressão teatral etc.

Algumas disciplinas também foram significativas nesse processo formativo e citarei as experiências que acionaram em mim mais intensivamente elementos estéticos: uma delas foi Imagem, corpo e educação ${ }^{6}$. Mesmo sendo uma disciplina eminentemente discursiva em formato de aula-conferência - foi fundamental para minha reflexão sobre o tema em estudo. Além disso, a professora trabalhou, em toda a disciplina ${ }^{7}$, com imagens sobre 0

\footnotetext{
5 O título da referida dissertação de mestrado é: "Os desejos de participação no processo do Orçamento Participativo em Icapuí-Ce: um olhar sociopoético" (UFC, 2002).

${ }^{6}$ Ministrada pela professora Carmem Lúcia Soares.

7 A intenção da disciplina, expressa em sua ementa, foi [...] analisar o caráter histórico das transformações do corpo em objeto de conhecimento, realçando assim, antigos/modernos problemas e cuidados de si, tais como:
} 
corpo ao longo da história, mostrando um rico acervo de obras de arte - reprodução de quadros mostrados em slides. O trabalho com imagens foi muito significativo, por instigar a reflexão, na perspectiva apontada em Herbert Read (2001, p. 55): "[...] na medida em que a forma do pensamento deve receber material genuíno com o qual possa trabalhar, mais e mais imagens devem ser utilizadas em nosso processo de pensar".

Outra disciplina significativa para minha educação estética foi Histórias de iniciação na $a_{r t e}{ }^{8}$. Nela fizemos estudos e debates sobre diversas biografias de artistas, buscando responder a questões como: o que o motivou a se tornar artista? Que estímulos ou dispositivos foram acionados ao longo de sua vida para isso? Além disso, tivemos que elaborar um texto para apresentar aos colegas, fazendo relação de alguma biografia de artista escolhido com a nossa vida e escolhas - artísticas, de pesquisa, de vida etc. Pincei Graciliano Ramos para expor a biografia, pois o Escritor, sendo do Nordeste (Alagoas) e havendo residido em Pernambuco, tem muita relação com a minha trajetória de vida. Discorro sobre esta identificação no texto que fiz para a disciplina, intitulado "Infância, infâncias" em que busco articular a infância de Graciliano com a de meus entes familiares.

Participar destas e de outras disciplinas (como o Seminário Avançado I: Leituras transversais de Michel Foucault: A coragem da verdade, com o professor Silvio Gallo; o Seminário Avançado II: Ensino Superior como campo do conhecimento e campo político, com as professoras Ana Maria F. Almeida e Helena M. Sampaio, Filosofia da Educação, com o Prof. René Trentin; Currículo, cotidiano escolar e formação de professores, com a professora Maria Inês P. Rosa), foram de significativa importância, tanto para perceber e apreender as diversas abordagens teóricas trazidas por parte de cada professor, como também, para vivenciar perspectivas metodológicas distintas em cada disciplina cursada, o que me fez ampliar o repertório didático e teórico.

Em 2013.2, tive ainda importante experiência formativa no Programa de Estágio Docente - PED - na disciplina Estágio Supervisionado, ministrada por meu orientador, Rogério Moura, e que, além das atividades concernentes às práticas de estágio - apoio aos estudantes e acompanhamento das práticas, elaboração de relatórios de observação, subsídio às aulas teórico-práticas etc. - elaborei ainda dois textos reflexivos referentes às

juventude e beleza, hábitos higiênicos, exercícios físicos e saúde, modificações corporais entre outros. A constatação de que gestos, expressões, hábitos de se alimentar, de amar, práticas de higiene, modos de divertirse, praticar exercícios físicos, potencializar e agenciar forças físicas que mudam com as épocas e com a sociedade nas quais são engendradas, dão ao corpo uma historicidade que testemunha as muitas e múltiplas transformações, e que se revela como lugar da memória individual e social.

8 Ministrada pela professora Ana Angélica Albano. 
minhas experiências na citada disciplina. Um deles intitula-se "Dimensões formativas do estágio supervisionado: uma experiência" em que faço uma descrição refletida sobre minhas práticas de estágio como estudante de graduação e, posteriormente, na qualidade de professora de Estágio; o outro texto, intitulado Experiências estético-formativas no Programa de Estágio Docente - PED - da disciplina Estágio Supervisionado II (UNICAMP), é onde faço uma análise das atividades realizadas na disciplina e que foram permeadas pelo fomento à experimentação estética, guiada pela perspectiva das aulas-oficina (MOURA, 2010). Além dessa produção textual, contribuí para sistematizar um levantamento feito sobre a situação dos estágios na UNICAMP. Com base em questionários respondidos pelos professores-supervisores, estruturei os dados em gráficos e desenvolvi uma análise destes para apresentação no colegiado do Curso de Pedagogia da Instituição.

O Programa de Pós-Graduação em Educação da UNICAMP, desde 2012.1, me possibilitou aprofundar reflexões e leituras, as relacionando a esta pesquisa, além de exercitar o olhar crítico-comparativo acerca dos currículos de formação de pedagogos da UNICAMP e da UECE, o que me trouxe diversos elementos para análises.

Em 2014.1, inseri-me no Grupo de Investigações sobre Arte, Ensino e História (IARTEH), vinculado ao Programa de Pós-Graduação em Educação (PPGE) da UECE e coordenado pelo professor Albio Sales. O Grupo tem reuniões sistemáticas quinzenais e desenvolve diversos estudos, discussões e experimentações estéticas, envolvendo as pesquisas dos integrantes. Além da participação nesse Grupo, me inseri na disciplina Teorias e abordagens investigativas sobre formação, didática e trabalho docente, também do PPGE/UECE, e que subsidiou as reflexões sobre saberes e formação docente posta nos limites desta pesquisa. A disciplina referida foi ministrada pelos professores: Jacques Therrien, Socorro Lucena e Marina Maciel. Atualmente faço parte do corpo docente que colabora com o PPGE/UECE, estando inserida na Linha Formação, Didática e Trabalho Docente (Núcleo Arte, Memória e Formação).

No âmbito da UECE, como professora, comecei a pensar e realizar formas de atuação teatral e aulas-oficina, tanto na própria sala de aula, no âmbito do exercício das diversas disciplinas, como em forma de projeto de extensão e de pesquisa universitária. Foi quando eu e outra professora criamos o Núcleo de Artes Cênicas da FACEDI - NACE (desde 2006). Junto a isso, comecei a desenvolver uma pesquisa nas escolas de Itapipoca-CE sobre as realidades do ensino de artes, juntamente com três bolsistas (de 2007 a 2009), sendo que

\footnotetext{
${ }^{9}$ Todas essas experiências de Estágio Docente realizado na UNICAMP foram dissertadas e publicadas como artigo intitulado "Formação pedagógica e estética na disciplina Estágio Supervisionado: aprendizagens docentes de estudantes universitários", na Revista Poiésis, V. 10, n 17, 2016, p. 270-291.
} 
venho dando continuidade à realização de pesquisas na perspectiva de integrar ensino, pesquisa e extensão, envolvendo os estudantes bolsistas e voluntários interessados.

\section{Aprendizagens e "ensinagens" significativas na UECE: (auto)formação estética no calor da ação profissional}

Percebendo a necessidade dos professores formadores desenvolverem sua própria sensibilidade, sua própria educação estética, em contínuo processo, coaduno com o olhar de Duarte Júnior (2010, p. 31) quando afirma que, "[...] na realidade, uma educação sensível só pode ser levada a efeito por educadores cujas sensibilidades tenham sido desenvolvidas e cuidadas, tenham sido trabalhadas como fonte primeira dos saberes e conhecimentos que se pode obter acerca do mundo".

Sendo a educação estética um processo de produção de sensibilidades, pode-se apontar a arte como um dos principais elementos acionadores dessa educação. Daí a necessidade de sua defesa e aprofundamento por parte de educadores e é nesse caminho que também busco direcionar minhas intervenções pedagógicas.

Atuo na UECE como professora desde 2001 - entre contratos como substituta e, de 2005 até hoje, como efetiva -, fato este que me trouxe muitas aprendizagens significativas e engrandecimento profissional. Dentro de meu campo de atuação, o da Pedagogia, venho priorizando as temáticas e componentes curriculares referentes à Arte-educação ${ }^{10}$.

Por uma identificação com o tema Arte-Educação, busco aprofundar-me nos estudos e pesquisas teórico-práticas sobre o assunto. Um marco importantíssimo nessa busca foi a participação em um curso de especialização em Metodologia do Ensino de Artes (2007). Fiz este curso na UECE e nele havia uma diversidade de pessoas que buscavam formação teórico-prática e experiências estéticas. Professores e artistas de variadas linguagens compunham o grupo de estudantes. Apesar de essa formação não garantir aprofundamento em nenhuma linguagem artística específica, pudemos minimamente refletir e experimentar modos de trabalhar com arte nas atuações pedagógicoprofissionais, bem como, vivenciar momentos de produção artística. A atuação docente no âmbito dessas disciplinas, por mim ministradas, e desses cursos de que participei, me

\footnotetext{
10 Faço parte do Colegiado do Curso de Pedagogia da FACEDI/UECE e, ao longo de minha trajetória nessa Instituição, ministrei disciplinas do Setor de Estudos "Fundamentos Históricos, Legais e Normativos da Educação" (no qual estou lotada), tendo já atuado nas disciplinas História da Educação I e II, História do Ceará, Introdução à Educação, Estrutura e Funcionamento da Educação Básica, Política e Planejamento Educacional. Além dessas, ministrei as disciplinas Didática, Estágio Supervisionado e Ensino de História e Geografia do setor de Estudos "Teoria e Prática da Educação". De 2010 a 2011, ministrei as disciplinas "Educação e Diversidade" e "ArteEducação", do Setor de Estudos "Tópicos Especiais em Educação", ante as demandas da Instituição por professores que sejam lotados nessa área, mas principalmente por uma vontade minha de ministrá-las.
} 
possibilitou o acesso a diversas leituras e experiências significativas, o que ensejou crescimento profissional e também pessoal, pois as relações sociais constituídas com os estudantes e colegas de trabalho, ao longo de todo esse tempo, representaram um campo fértil de criação de saberes, permeado por desafios, alegrias e tensões.

Em meio a tudo isso, desenvolvi, nos últimos anos, uma série de atividades acadêmicoprofissionais no que se refere à formação continuada, produção científica, técnica e artístico-cultural (minha e dos estudantes). Com a reflexão sobre essas atividades, suscito algumas considerações pertinentes, enfocando as aprendizagens, ganhos, desafios e dificuldades por mim vivenciados, inserida numa coletividade, no âmbito do exercício profissional. Na busca do aprofundamento da consciência de si, do amadurecimento pessoal e profissional, fui inventando estratégias de envolver o outro - seja ele estudante ou mesmo outro colega docente,

[...] movemos o outro e a nós mesmos para viver experiências estéticas, não mais da maneira espontaneísta da escola que só valorizava o fazer, mas na consciência de si, na percepção dos próprios processos de criar, pensar, produzir significados, de se colocar vivo na experiência, de compartilhá-la com outros na conversa que se torna espaço do diálogo, do enfrentamento da diferença, da inquietude da desaprendizagem de nossas amarras conceituais (MARTINS, 2011, p. 314).

Como pessoa interessada e preocupada com a educação estética dos alunos, e também minha, realizei pelo NACE, constantes atividades de capacitação, produção artística e exibição de peças teatrais e de narração de histórias. Esse trabalho de coordenação era dividido com outra professora da Faculdade, que se volta mais diretamente para a narração de histórias, ficando sob minha coordenação as atividades formativas em teatro, promoção de mostras e eventos artísticos, articulação de facilitadores para ministrar oficinas, compra e elaboração de materiais (adereços, pesquisas de textos). Essa atividade extensionista mobiliza tanto pessoas da Faculdade - dentre alunos e professores - como estudantes das escolas locais, proporcionando maior vivacidade no cotidiano formativo da universidade ${ }^{11}$.

Em relação às atividades de pesquisa envolvendo o tema da educação estético-artística, desenvolvi, de 2007 a 2009, juntamente com dois bolsistas, o estudo intitulado Relações transversais entre o movimento artístico e as escolas de Itapipoca-CE na trajetória de

\footnotetext{
${ }^{11} \mathrm{Em}$ 2011, as atividades de extensão foram financiadas pela CAPES, com suporte no Projeto Novos Talentos, num edital em que o grupo foi selecionado (com vigência em todo o ano citado). O Projeto Novos Talentos envolveu professores e alunos dos três cursos da FACEDI (Pedagogia, Biologia e Química) e a comunidade regional do litoral oeste, pois nossa Faculdade constitui um pólo de formação de professores que privilegia vários municípios, com uma rica diversidade cultural, incluindo escola indígena, organizações dos movimentos sociais, comunidades quilombolas e outras representações de instituições socioeducativas.
} 
institucionalização da arte-educação: a perspectiva das redes de movimentos; de 2009 a 2010, a pesquisa Saberes docentes mobilizados no ensino de Artes de Itapipoca-CE; de 2016 a 2017, Perfil formativo de arte-educadores de Itapipoca-Ce: percepções de egressos do curso de Pedagogia da UECE/FACEDI e, de 2017 a 2018, Pesquisas sobre ensino de Artes em cursos de Pedagogia da UECE: campos de interesses e perfil metodológico. Essas experiências de pesquisa possibilitaram, em especial, o conhecimento da realidade de municípios cearenses acerca da promoção e da valorização do ensino de Artes no Estado do Ceará e esse conhecimento também me permitiu direcionar o trabalho acadêmico nos âmbitos do ensino, da pesquisa e da extensão, percebendo e vivenciando as necessárias articulações entre eles.

De 2005 a 2008, participei da coordenação da elaboração do novo projeto políticopedagógico - PPP - do Curso de Pedagogia da FACEDI/UECE ${ }^{12}$. Nessa elaboração, busquei instigar reflexões sobre uma necessária proposição de educação estética com suporte em elementos arte-educativos e isso foi beneficiado no novo documento, tanto como disciplina obrigatória (Arte-Educação) como mediante atividades complementares e projetos de extensão e pesquisa.

No biênio 2008-2009, destaco um momento importante de minha atuação acadêmicoprofissional, que ocorreu junto ao Sindicato dos Docentes da UECE - SINDUECE - onde assumi o cargo de secretária geral. No exercício da militância político-representativa, pude também experimentar algumas ações políticas de caráter estético que exigiam muita criatividade e capacidade de encantar e de envolver elementos próprios de uma prática artística; por exemplo, na organização de assembleias gerais, de passeatas, de greves, em que tínhamos que elaborar vídeos, cartazes, materiais diversos que tivessem o poder de chamar a atenção da mídia e dos próprios professores e estudantes sobre nossas reivindicações. O estandarte Em Defesa da UECE que criei (citado anteriormente) foi muito exposto nas assembleias.

Em maio de 2009, publiquei meu primeiro livro de poemas, intitulado (F)Ponte de Desejos. Essa experiência me instigou a dar continuidade à escrita poética, bem como, a querer divulgar uma produção de teor mais subjetivo e artístico também no meio acadêmico, dada a repercussão positiva que este livro teve entre alunos, professores e outras pessoas de lugares diversos. Após essa publicação, ganhei prêmios de poesias, tendo alguns poemas sido publicados em mais dois livros (coletâneas) e em uma revista literária. Minha segunda

${ }^{12}$ Esse processo de elaboração do novo PPP da pedagogia da FACEDI se iniciou desde finais de 2003 e se estendeu até 2008. Atualmente, 2014, o documento está passando por alterações. 
publicação de livro de poemas, é Botão de Flor e Certos Cactos, lançado pela EdUECE em 2015.

Em 2010, organizei, com outros três colegas de trabalho, o primeiro livro da Coleção EducAções - Vozes da FACEDI: reflexões, experiências e perspectivas em educação, que representou um projeto coletivo de pessoas que compuseram, e ainda compõem, a história da FACEDI e que refletem propositivamente sobre o seu trabalho na referida Instituição. O livro é, para nós, um marco inicial de produção acadêmica conjunta e retrata a preocupação que temos em registrar e divulgar nossas ações político-pedagógicas. $O$ capítulo que escrevi no referido livro intitula-se "A defesa do ensino de artes a partir das articulações entre o movimento de artistas e arte-educadores (representado pela AARTI) e as instituições educativas de Itapipoca-CE: a perspectiva das redes de movimentos", e foi a sistematização da pesquisa referida anteriormente. Lançamos ainda, pela EdUECE, o segundo livro da Coleção EducAções, de autoria coletiva e do qual também fui organizadora, intitulado Políticas educacionais: práticas e proposições (2014). Este, por sua vez, teve abrangência maior no referente à diversidade de autores, que eram vinculados a várias universidades do País. Este livro se subdividiu em três eixos: educação estética, formação e trabalho docente e políticas e avaliação educacional. Finalmente, elaboramos o terceiro livro da coleção EducAções Saberes e Autonomia Docente: história, formação e profissionalização, lançado em 2018, reflete acerca dos saberes elaborados na formação e nas práticas pedagógicas em variados campos de conhecimento, sendo mediados pela compreensão de que o educador necessita produzir e legitimar sua autonomia.

Vi, com tudo isso, que o trabalho docente é uma atividade complexa, a envolver diversas dimensões mediadas e costuradas pela experiência cotidiana (TARDIF, 2007, p.21): "[...] os saberes oriundos da experiência de trabalho cotidiana parecem constituir o alicerce da prática e da competência profissionais, pois essa experiência é, para o professor, a condição para a aquisição e a produção de seus próprios saberes profissionais".

Apreendi, com todas essas reflexões, a compreensão de que todo docente precisa sentirse e vivenciar continuamente a experiência de ser também discente, para referir-me às ideias de Paulo Freire (2006), no sentido da dimensão investigativa e crítica que ele precisa assumir, na elaboração de saberes essenciais para suas ações pedagógicas:

Ensinar inexiste sem aprender e vice-versa e foi aprendendo socialmente que, historicamente, mulheres e homens descobriram que era possível ensinar. (...) quando vivemos a autenticidade exigida pela prática de ensinar-aprender participamos de uma 
experiência total, diretiva, política, ideológica, gnosiológica, pedagógica, estética e ética, em que a boniteza deve achar-se de mãos dadas com a decência e com a seriedade (FREIRE, 2006, p.2324).

$\mathrm{Na}$ trajetória acadêmico-profissional-artística ora descrita, vivenciei, muito intensamente, algumas ações docentes no âmbito da gestão, do ensino, da pesquisa e da extensão ${ }^{13}$ e percebi que essas quatro instâncias são complementares entre si e bastante enriquecedoras em matéria de conhecimentos e experiências. Considero, pois, que tanto a UECE contribui para meu crescimento pessoal e profissional como eu concorro para o enriquecimento da FACEDI/UECE no âmbito das ações acadêmico-científicas e artísticopedagógicas. Observando essa trajetória de apropriação de saberes estéticos, descobri que passei a atribuir importância e situei como necessária uma educação estética baseada em minhas experiências; pela experimentação estética, vi ampliada minha sensibilidade e, consequentemente, minha percepção sobre o mundo.

O caminho formativo da educação estética, precisa, pois, ser criado a partir de vivências concretas, sendo que essas vivências ou experiências,

[...] não se restringem à simples contemplação de obras de arte, seja ouvindo música, seja assistindo a teatro, seja frequentando museus. Elas devem, sobretudo, principiar por uma relação dos sentidos com a realidade que se tem ao redor, composta por estímulos visuais, táteis, auditivos, olfativos e gustativos. Há um mundo natural e cultural que precisa ser frequentado com os sentidos atentos [...] (DUARTE JUNIOR, 2010, p. 30).

Nessa direção, alimento estudos e intervenções educativas, criando possibilidades aos educandos, tanto de vivenciar como de refletir sobre experiências estéticas, sendo guiada, particularmente, pelo caminho das Artes.

\section{Finalizando...}

Pensar em (auto)formação, necessariamente, requer que ela seja situada no contexto em que o docente está inserido, bem como, que sejam identificados os sujeitos que com ele interage, pois toda formação é, ao mesmo tempo, produzida coletiva e individualmente. Foi partindo dessa assertiva que analisei meu processo estético-formativo e elenquei as lacunas e grandezas dessa formação.

\footnotetext{
13 Dentre essas atividades, relaciono: orientações de bolsistas de monitoria e de pesquisa; de variadas monografias de graduação e de especialização; participações em bancas avaliadoras diversas; organizações de eventos, coordenação de projeto extensionista etc.
} 
Autores como Freire (2006) e Tardif (2007) apontam uma variedade de saberes que são exigidos na constituição da docência e, dentre esses saberes, está o estético - como componente fundamental de aperfeiçoamento da sensibilidade e da percepção humana.

Há, como observado, singularidades no tornar-se docente, ou seja, cada docente, com sua história, sua subjetividade, seu modo próprio de estar no mundo também cria seu perfil profissional e desenvolve sua profissionalização como processo repleto de peculiaridades, dado suas vivências num contexto sociocultural próprios.

Nessa direção, a formação docente de bases estéticas exige um amplo e contínuo acesso a vivências estético-culturais, especialmente artísticas, que envolvam possibilidades de apreciação, criação e análises de obras de arte. Em particular, na minha formação, optei por abraçar o que Suassuna (2008) tanto defendia, que era buscar apropriar-se de uma cultura contextualizada e que faça parte das vivências e identificações do sujeito, ou seja, busquei me alimentar e explorar curiosa e criativamente elementos da cultura brasileira, mais propriamente do Nordeste. Junte-se a isso, o fato de que cada docente, pela sua singular história de vida e acessos a formações e acervos culturais, possui um repertório e um modo peculiar de tornar-se docente, o que cria um conjunto diversificado de docentes em atuação no campo da educação estética.

Com tudo isso percebo, agora de modo muito mais nítido, o quanto meu perfil docente e meu repertório cultural é diferente em relação ao de meus colegas de profissão, e viceversa. $E$, obviamente, essa diferença é resultado das trajetórias de vida e profissionalização de cada um.

Possibilitar uma educação estética na formação docente tende a favorecer o perfil destes como mediadores culturais (MARTINS, 2014), profissionais que tanto produzem como mobilizam saberes culturais, especialmente artísticos.

Mesmo em meio às limitações formativas, relativamente por falta de acessos e aprofundamentos de alguns saberes estéticos, ou ainda aprendendo nas informalidades, percebo que o mais essencial ao analisar minha trajetória é realçar as grandezas dessa formação - as descobertas dos cursos livres, a ousadia das experimentações em salas de aula e das pesquisas individuais - pois, com tudo isso, elaborei um modo de fazer-me docente; dito de outra forma, compus singularidades que manifestam as belezas de ser e constituir-me docente cotidianamente.

\section{Referências}

Revista Digital do LAV - Santa Maria - vol. 11, n. 2, p.20 - 39 - mai./ago. 2018 ISSN 1983 - 7348 http://dx.doi.org/10.5902/1983734830973 
BARCELOS, V.; SILVA, IV.S. "Antropofagia cultural brasileira e educação: Contribuições ecologistas para uma pedagogia da 'devoração'". Revista Poiesis, n.1, v. 1, p. 20-41, jan./abr. 2008.

BOAL, A. Teatro do Oprimido e outras poéticas políticas. Rio de Janeiro: Civilização Brasileira, 2005, $223 \mathrm{p}$.

DUARTE JR., J.F. A Montanha e o videogame: escritos sobre educação. Campinas-SP: Papirus, 2010, 160 p.

FREIRE, P. Pedagogia da Autonomia: saberes necessários à prática educativa. São Paulo: Paz e Terra, 2006, 148 p.

JOSSO, M.C. "A transformação de si a partir da narração de histórias de vida". Revista Educação. Porto Alegre, Ano XXX, n. 3 (63), p. 413-438, set./dez. 2007.

MARTINS, M.C.F. "Arte, só na aula de arte?". Revista Educação. Porto Alegre, v. 34, n.3, p. 311-316, set./dez. 2011.

"Entre [con]tatos, nuvens e chuviscos mediadores. In: MARTINS, M. C.(org.). Pensar juntos mediação cultural: [entre]laçando experiências e conceitos. São Paulo: Terracota, 2014. p. 213-229.

MORAES, A.C. Botão de flor e certos cactos. Fortaleza: Editora da Universidade Estadual do Ceará - EdUECE, 2015.

READ, H. A educação pela arte. São Paulo: Martins Fontes, 2001, 366 p.

SCHÖN, D. Educando o profissional reflexivo: um novo design para o ensino e a aprendizagem. Porto Alegre: ARTMED, 2000, 256 p.

SOUZA, E. Clementino. "Histórias de vida, escritas de si e abordagem experiencial". In: SOUZA, E. Clementino/MIGNOT, A. C. Venâncio (orgs.). Histórias de Vida e Formação de Professores. Rio de Janeiro: Quartet: FAPERJ, 2008. p. 89-98.

SUASSUNA, A. Almanaque Armorial. 2. ed. Rio de Janeiro: José Olympio, 2008, 293p.

TARDIF, M. Saberes docentes e formação profissional. 8.ed. Petrópolis: Vozes, 2007, $325 p$.

Revista Digital do LAV - Santa Maria - vol. 11, n. 2, p.20 - 39 - mai./ago. 2018 ISSN 1983 - 7348 http://dx.doi.org/10.5902/1983734830973 
'Professora Adjunta da Universidade Estadual do Ceará - UECE. Doutora em Educação pela - Universidade Estadual de Campinas - UNICAMP. Mestre em Educação Brasileira pela Universidade Federal do Ceará - UFC. Grupo de Pesquisa: Investigações em Arte, Ensino e História - IARTEH (Programa de Pós-Graduação em Educação/PPGE-UECE).

Como citar esse artigo:

MORAES, Ana Cristina. Educação estética e (auto)formatação: sungularidades no tornarse docente. Revista Digital do LAV, Santa Maria: UFSM, v. 11, n. 2, p. 20 - 39, mai./ago. 2018. 